\title{
STRATEGI PEMBINAAN DAKWAH \\ SYARHIL QURAN DI PADEPOKAN SYARHIL QURAN LAMPUNG
}

\author{
Handieni Fajrianty \\ Universitas Islam Negeri Syarif Hidayatullah Jakarta, Indonesia \\ handienioke@gmail.com \\ Ressi Susanti \\ Universitas Islam Negeri Raden Intan Lampung, Indonesia \\ ressi.susanti@gmail.com
}

\begin{abstract}
Abstrak. Dakwah syarh al-Quran diperdengarkan dan ditampilkan pertama kali dalam ajang MTQ Nasional ke XV di Bandar Lampung pada tahun 1988. Konsep dakwah syarh al-Quran adalah dakwah dengan seni yang pertunjukkan oleh tiga orang dalam satu grup. Hingga tahun 2002, dakwah syarh al-Quran belum memiliki tempatyang baik di hadapan masyarakat, hingga lahirnya Padepokan Syarhil Quran Lampung yang secara intensif melatih dan membina para santri agar mampu sukses dalam pertandingan atau musabaqah dalam ajang MTQ baik tingkat kabupaten/kota, provinsi maupun nasional, juga sukses dalam performa mereka di hadapan masyarakat, barulah dakwah syarh al-Quran dikenal dan responsif di tengah masyarakat. Adapun strategi pembinaan dakwah yang dilakukan di tubuh Padepokan Syarh al-Quran adalah dengan pembinaan hafalan naskah syarahan al-Quran, pembinaan mental dari setiap anggota, latihan vokal dan performa tampil, pembinaan spiritual, dan pembinaan kekeluargaan.
\end{abstract}

Kata Kunci: Strategi Pembinaan, Dakwah Syarh al-Quran, Padepokan Syarhil Quran Lampung

Abstract. Syarhil al-Quranin da'wah was first introduced and performed at the National MTQ XV in Bandar Lampung in 1988. The concept of Syarhil al-Quran da'wah is an art performance in a group of three people. Until 2002, this da'wah has not gotten a good accepteance in community. Then, the Padepokan for Syarhil Quran in Lampung was established to intensively train and coach santri in order to succeed the comig competition in the regional and national levels. Furthermore, they are to succeed performing in front of the community so that syarhil Quran is well known. The coaching strategy implemented at the padepokan are script memorising, mental coaching, vocal and performance exercising, spiritual coaching, and kinship coaching. 
Key words : Coaching strategy, Syarhil al-Quran da'wah, the padepokan for Syarhil Quran Lampung

\section{A. Pendahuluan}

Al-Quran adalah wahyu Allah yang disampaikan kepada Rasul-Nya berisi pedoman, petunjuk, dan sentral segala wacana ideologi kehidupan untuk mencapai kesuksesan dan kebahagiaan dunia dan akhirat. Dalam rangka menjadikan al-Quran sebagai petunjuk dan pedoman dalam kehidupan umat manusia, maka dalam menyelesaikan berbagai problem kehidupan umat tersebut, maka diperlukan langkah-langkah konkret berupa proses pengkajian, pemahaman, penafsiran, dan sosialisasi nilai-nilai al-Quran di tengah kehidupan bermasyarakat. Itulah tujuan utama dari dakwah Islam berbasis al-Quran, yakni membangun nilai-nilai Islam (qurani) di tengah-tengah kehidupan manusia.

Berdasarkan petunjuk tersebut, dipahami bahwa dakwah tidak hanya terklasifikasi satu model performa berupa pada ceramah di majelis-majelis, mimbar, forum, dan podium, namun dakwah adalah tugas dari setiap individu yang bernama muslim yang menanggung amanah dakwah dalam dirinya. Akan tetapi, karena al-Quran diturunkan dalam konteks bi al-lisan, maka secara spesifik tulisan ini akan menelisik konsep dakwah al-Quran dengan model verbatim tersebut di tengah-tengah masyarakat berupa Dakwah Syarhil Quran.

Di tengah pesatnya perkembangan teknologi komunikasi, metode dakwah bi al-lisan menemui tantangan berat. Minat mendengarkan ceramah yang berbeda-beda setiap orangnya, tingkat kecakapan mubalig maupun dai yang kurang expert, media massa yang tidak memberikan prime time pada acara-acara kajian Islami dan lain sebagainya. Hal-hal inilah yang mendorong berbagai macam metode dakwah bi al-lisan hadir.

Salah satu metode bi al-lisan adalah tablig. Tablig adalah metode penyampaian tentang pesan-pesan moral, spiritual dan nilai-nilai Islam dalam kehidupan yang dilakukan melalui komunikasi kelompok besar (large group communication). Metode penyampaian pesan ini membutuhkan kecakapan public speaking. Seiring dengan perkembangan selera masyarakat, metode tablig dituntut untuk terus berinovasi dalam menyampaikan pesan-pesan Islami demi membangun karakter bangsa. Akhirnya muncullah salah satu metode tablig yang menyatukan teknik teatrikal, kecakapan orasi, kehandalan melantunkan ayat al-Quran, serta kecakapan menjelaskan isi dan kandungan al-Quran. Model tablig seperti ini dalam dunia dakwah dikenal dengan Dakwah Syarh al-Quran atau Syarhil Quran.

Model dakwah syarh al-Quran diawali di Indonesia dalam bentuk perlombaan yang tergolong dalam cabang musabaqah di Musabaqah Tilawah al-Quran (MTQ). Pada konteks musabaqah tersebut, cabang syarh al-Quran tergolong unik karena memiliki metode yang tidak biasa dalam meyampaikan isi dan kandungan al-Quran dengan melibatkan kerja sama dari tiga unsur atau pelaku, yakni:

1. Pensyarah: Orator atau penceramah yang menguraikan materi syarahan al-Quran dengan model retorika khusus.

2. Penerjemah (Saritilawah): Seorang penerjemah ayat al-Quran yang telah dibaca oleh seorang pembaca ayat al-Quran yang spesifik mengenai tema kajian yang dibawakan oleh pensyarah.

3. Pelantun Ayat (Qari atau Qariah): seorang ahli pembaca al-Quran dengan model mujawwad atas dasar riwayat Hafsh dari 'Ashim. 
Model dakwah syarh al-Quran seperti ini secara kelembagaan telah dilaksanaan pembinaan yang reguler di Padepokan Syarhil Quran Lampung. Padepokan Syarhil Quran Lampung adalah satu-satunya lembaga pembinaan dakwah syarh al-Quran yang ada di Indonesia dengan strategi pembinaan yang terstruktur, rapih, juga pemasaran yang baik. Sebagai pusat pendidikan dakwah yang unik karena terkonsentrasi pada cabang syarh alQuran inilah maka menjadi urgen untuk dapat menelaah secara mendalam bagaimana startegi dakwah Padepokan Syarh al-Quran Lampung dalam pengembangan dakwah syarh al-Quran.

\section{B. Strategi Dakwah dan Syarh al- Quran}

Dakwah berasal dari bahasa Arab "da'wah" yang merupakan bentuk mashdar dari $d a^{\prime} a-$ yad'u yang berarti seruan, ajakan, atau panggilan. ${ }^{1}$ Seruan ini dapat dilakukan melalui katakata atau perbuatan. Dalam al-Quran banyak ayat yang berkaitan dengan dakwah, baik menyangkut materi, metodologi, subjek maupun objeknya. Secara bahasa, dakwah berarti memanggil, mengajak, atau menyeru. Menurut Muhammad al-Wakil, dakwah artinya mengumpulkan manusia dalam kebaikan dan menunjukkan mereka kepada jalan yang benar dengan cara amar makruf nahi mungkar. ${ }^{2}$ Sandarannya adalah Firman Allah Swt. di dalam al-Quran:

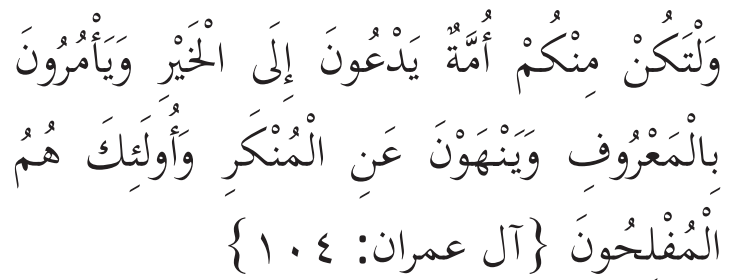

Artinya: "Dan hendaklah ada di antara kamu segolongan umat yang mengajak

A. Ilyas Ismail, Paradigma Dakwah Sayyid Quthub: Rekonstruksi Pemikiran Dakwah Harakah, (Jakarta: Penamadani. 2008), h. 144 Ibid., h. 125 kepada kebaikan, menyuruh kepada yang makrufdan mencegah dariyang mungkar, mereka itulah orang-orang yang beruntung." (QS. Ali Imran [3]: 104)

Adapun makna dari strategi adalah, penggabungan antara perencanaan dan manajemen untuk mencapai suatu tujuan dengan taktik tertentu dalam operasionalisasinya. Toto Tasmara menjelaskan bahwa komunikasi berasal dari bahasa Latin yaitu communicare yang artinya partisipasi atau komunikasi juga bisa berasal dari kata commones yang artinya sama. Dengan demikian, secara sangat sederhana, dapat kita katakan bahwa seseorang yang berkomunikasi berarti mengharapkan agar orang lain dapat ikut serta berpartisipasi atau bertindak sama sesuai dengan tujuan, harapan atau isi pesan yang disampaikannya. ${ }^{3}$

Strategi komunikasi adalah paduan dari perencanaan komunikasi (communication planning) dan manajemen komunikasi (communication management) untuk mencapai suatu tujuan ${ }^{4}$. Untuk itu, strategi komunikasi harus dapat menunjukan bagaimana operasionalnya secara taktis dengan menentukan efek yang diharapkan melalui beberapa pertanyaan:

1. Siapa sasarannya,

2. Apa pesan yang akan disampaikan.

3. Kapan penyampaiannya.

4. Mengapa harus disampaikan.

5. Di mana lokasi penyampaian pesannya Effendy mengatakan, ${ }^{5}$ strategi yang baik secara makro (planned multimedia strategy) mempunyai fungsi ganda, yaitu :

1. Menyebarluaskan pesan komunikasi yang bersifat informatif, persuasif, dan instruktif

Toto Tasmara, Komunikasi Dakwah. (Jakarta: Graha Media Pratama, 1997), h. 1

Onong Uchjana Effendy, Ilmu, Teori, dan Filsafat Komunikasi, (Bandung: Citra Aditya Bakti, 2003), h. 301

Onong Uchjana Effendy, Peranan Komunikasi Massa Dalam Pembangunan, (Yogyakarta: Gadjah Mada University, 1987), h. 23 
secara sistimatik kepada sasaran untuk memperoleh hasil yang optimal.

2. Menjembatani "cultural gap" akibat kemudahan diperolehnya dan dioperasionalkannya media massa yang jika dibiarkan akan merusak nilai-nilai budaya.

Strategi dan perencanaan (planning) tidak dapat dipisahkan dan saling berkaitan. Menciptakan strategi yang efektif dalam penyampaian komunikasi dibutuhkan perencanaan yang matang dan terukur. Perencanaan yang bagus bisa dijadikan koridor kerja bagi orang-orang yang melaksanakan misi komunikasi. Strategi akan membimbing kita ke arah mana komunikasi digerakkan, mulai dari proses persiapan hingga menyampaikan pesan pada publik. Strategi komunikasi bersifat dinamis sesuai dengan perkembangan zaman dan peradaban manusia. Skinner ${ }^{6}$ menemukan bahwa komunikasi akan berlangsung selama orang mempunyai apa yang disebut expection of reward atau adanya harapan untuk memperoleh keuntungan dalam praktik komunikasi. Keuntungan tersebut dapat berbentuk:

1. Personal Needs, kebutuhan pribadi semisal makan dan minum.

2. Social Needs, kebutuhan untuk bergaul dengan orang lain.

3. God Needs, kebutuhan akan Tuhan.

Dilihat dari segi bahasa, kata dakwah berasal dari bahasa Arab, yakni da'wah, merupakan bentuk mashdar dari kata kerja da'a-yad'u, berarti seruan, ajakan, atau panggilan. Seruan dan panggilan ini dapat dilakukan dengan suara, kata-kata, atau perbuatan. ${ }^{7}$ Secara terminologi, dakwah adalah ajakan dan seruan kepada umat manusia untuk mengamalkan ajaran Islam. Maka dapat disimpulkan bahwa pengertian strategi komunikasi dakwah adalah

Rafy Sapuri, Psikologi Islam, (Jakarta: PT. Raja Grafindo Persada, 2009), h. 401

Ilyas Ismail, op.cit., h. 144 gabungan antara manajemen dan perencanaan yang secara taktis mengarahkan kegiatan penyampaian pesan, baik secara verbal dan non-verbal kepada pengamalan ajaran atau nilai-nilai keislaman.

Dalam konteks dakwah, menurut Arifin ${ }^{8}$ untuk menciptakan expaction of reward tersebut, strategi komunikasi haruslah memiliki empat rumusan, yang terdiri atas:

1. Mengenal khalayak: Untuk memaksimalkan keberhasilan dalam berkomunikasi, maka komunikator perlu mengenal kerangka referensi khalayak, sehingga tidak terjadi kesenjangan antara komunikator dengan komunikan yang menyebabkan pesan tidak tersampaikan dengan benar. Kerangka referensi khalayak adalah sebagi berikut: ${ }^{9}$

a. Kondisi kepribadian dan fisik yang menyangkut pengetahuan khalayak terhadap materi, kemampuan menerima pesan, dan kemampuan khalayak menerima bahasa pengantar.

b. Pengaruh kelompok dan masyarakat yang menyangkut nilai-nilai dan norma yang dianut.

c. Situasi tempat tinggal khalayak.

2. Menyusun Pesan: Yaitu menentukan tema dan materi. Syarat utamanya adalah mampu membangkitkan perhatian. Perhatian dijadikan tolak ukur untuk menilai keberhasilan komunikator dalam melakukan komunikasi. Dalam menetukan tema dan materi, dikenal dua bentuk penyajian permasalahan: ${ }^{10}$

a. One sides issue (sepihak). Dikenal pula sebagai top-down strategy, yaitu hanya mengemukakan hal yang positif, atau hal-hal yang negatif saja kepada khala-

Anwar Arifin, Strategi Komunikasi Sebuah Pengantar Ringkas, (Bandung: Amrico, 1994), h. 58-86

Rafy Sapuri, op.cit., h. 402

Ibid. 
yak untuk memengaruhi khalayak. Permasalahan dalam bentuk ini berisi konsepsi dari komunikator sematamata tanpa mengusik pendapat yang telah berkembang.

b. Both side issue (kedua belah pihak). Suatu permasalahan yang disajikan baik yang positif maupun negatif yang tujuannya untuk memengaruhi khalayak. Permasalahan diketengahkan baik konsepsi dari komunikator maupun konsepsi yang berkembang pada khalayak.

3. Menetapkan Metode: ${ }^{11}$ Yakni suatu rencana yang tersusun dan teratur yang berhubungan dengan cara penyajian. Beberapa macam metode cara penyajian adalah:

a. Repeatation Methods

Adalah cara memengaruhi khalayak dengan mengulang-ulang pesan. Tujuannya, agar khalayak dapat memperhatikan pesan dan tidak mudah melupakan pesan tersebut.

b. Canalizing

Cara memengaruhi khalayak dengan jalan menyediakan saluran-saluran tertentu untuk menguasai motif-motif khalayak untuk kemudian diubah sedikit-demi sedikit ke arah tujuan komunikator. Istilah lain yang muncul adalah start where the audience.

c. Informatif

Penyampaian sesuatu apa adanya, apa yang sesungguhnya di atas data dan fakta yang valid. Metode ini lebih ditujukan pada penggunaan akal pikiran khalayak dan bentuknya berupa pernyataan, penerangan, berita, dan sebagainya.

d. Persuasif

1 Ibid., h. 405
Memengaruhi khalayak dengan jalan membujuk yang digugah adalah pikiran dan perasaan. Tidak ada kesan-kesan yang menjurus kepada pemaksaan kehendak.

e. Edukatif

Memengaruhi khalayak dari satu pertanyaan umum yang dilontarkan dapat diwujudkan dalam bentuk pendapat, fakta, dan pengalaman.

\section{f. Kursif}

Cara memengaruhi khalayak dengan jalan memaksa. Khalayak dipaksa tanpa harus berpikir untuk menerima gagasan yang dilontarkan. Pesan jenis ini mengandung ancaman-ancaman.

4. Seleksi dan Penggunaan Media: Dalam menyusun pesan dari suatu komunikasi yang ingin dicapai haruslah selektif, dengan cara menyesuaikan keadaan dan kondisi khalayak. Penyesuaian khalayak akan memengaruhi penyesuaian media yang digunakan. Fungsi media adalah menyalurkan gagasaan, ide, informasi yang ditampung oleh opinion leader kepada khalayak komunikan.

Adapun mengenai Syarh al-Quran, secara etimologi syarh al-Quran berasal dari dua kata 'syarh' dan 'Quran'. Kata 'syarh' merupakan bentuk masdar dari fi'il madhi' 'syaraha' yang artinya menjelaskan atau menerangkan sesuatu'. Sedangkan al-Quran, merupakan bentuk masdar dari fi'il madhi' qara'a, yang artinya bacaan atau yang dibaca. Mengacu pada pengertian secara bahasa di atas, maka dapat dirumuskan bahwa syarh al-Quran adalah metode retorika atau tablig yang mendeskripsikan pesan-pesan dan kandungan al-Quran secara tematik (maudhu'i), yang disampaikan dalam bentuk ceramah keagamaan secara tatap muka dengan melibatkan tiga pelaku atau unsur, yaitu 
pensyarah, qari/qariah, dan saritilawah, dan ketiga unsur tersebut saling melengkapi. ${ }^{12}$

Secara historis, dakwah syarh al-Quran diawali dalam bentuk musabaqah di Musabaqah Tilawah al-Quran (MTQ). Pada awalnya syarh al-Quran ditampilkan layaknya ceramah biasa tanpa aturan yang baku, namun pada tahun 1980-an, para mahasiswa Fakultas Dakwah IAIN Sunan Gunung Djati (sekarang UIN Sunan Gunung Djati) melakukan inovasi yang apik dengan menggabungkan ceramah dengan seni teatrikal. Hal ini menimbulkan dua rekasi bersamaan, yaitu apresiasi dari sejumlah kalangan, sekaligus kontroversi dari kalangan lainnya. Apresiasi karena ini merupakan hal unik dan menarik serta menjadi inovasi dalam menyampaikan isi dan kandungan al-Quran terutama pada generasi muda. Sedangan kontroversi muncul dari kalangan salafiyah dan kalangan penceramah 'konvensional' karena dianggap mempermainkan ayat-ayat Allah.

Di balik itu semua, secara de jure, tidak diketahui dengan pasti kapan istilah Syarh alQuran atau terkenal dengan Syarhil Quran mulai hadir. Istilah Syarh al-Quran dikenal dalam dunia Musabaqah Tilawatil Quran. Karena memang Syarh al-Quran ini merupakan salah satu cabang dalam Musabaqah Tilawatil Quran, biasa dikenal dengan cabang Musabaqah Syarhil Quran yang lazim disingkat dengan nama MSQ. Menurut keterangan dalam kumpulan soal Fahm al-Quran LPTQ Nasional, Musabaqah Syarh al-Quran (MSQ) pertama kali diselenggarakan pada MTQ Nasional XV di Bandar Lampung tahun 1988. ${ }^{13}$

Adapun materi syarh al-Quran secara umum, strukturnya terdiri atas tiga bagian, ${ }^{14}$ yaitu; mukaddimah, isi dan penutup. Mukad-

Amirullah Syarbini, Bunga...op.cit., h. 4

Amirullah Syarbini, Training...op.cit., h. 3

Ahmad Rajafi, Narasi Syarhil Quran dan Model Pembinaannya, (Bandar Lampung: Anugerah Utama Raharja, 2013), h. 8 dimah berisi: salam, hamdalah, salawat, sapaan pada audiens, dan pengantar pada topik bahasan. Sedangkan bagian isi terdiri dari: ayat suci al-Quran, hadis, qaulun hakim, kaidah lughawi, kaidah ushl figh, asbabun nuzul (bila ada), syi'ir, contoh aktualisasi ayat dalam kehidupan. Sedangkan penutup berisi: kesimpulan, saran, imbauan, kesesuaian simpulan dengan isi, doa, dan salam.

Untuk mengetengahkan materi tersebut, penampilan syarhil Quran dilakukan oleh tiga orang dalam satu grup dengan tugas masingmasing yang saling mendukung. Pelaku atau unsur, yang masing-masing memiliki istilah sendiri sesuai tugasnya, yaitu: pensyarah, qari atau qariah, dan saritilawah.

1. Pensyarah

Pensyarah merupakan unsur pertama dan utama dalam penyampaian syarh al-Quran. Unsur inilah yang merupakan ujung tombak dan jantung dari syarh al-Quran. Tanpa pensyarah, syarh al-Quran tidak akan mungkin tersampaikan. Esensinya, pensyarah merupakan orang yang bertugas untuk menyampaikan materi syarahan dalam bentuk menjelaskan suatu topik tertentu yang mengacu pada beberapa ayat suci alQuran. ${ }^{15}$ Dalam dunia tablig, pensyarah bisa disebut sebagai mubalig. Dan dalam dunia komunikasi interpersonal, pensyarah dapat dikatakan sebagai public speaker.

Dalam dakwah syarh al-Quran, unsur pensyarah merupakan unsur tugas tertinggi. Dan dalam penyampaiannya, pensyarahlah yang memberikan komando kapan qari atau qariah dan saritilawah melaksanakan tugas mereka. Dengan kata lain, pensyarah adalah pemimpin dalam tim tablig syarh al-Quran.

2. Qari atau Qariah

Amirullah Syarbini, Training...op.cit., h. 6 
Secara etimologi, kata qari berarti pembaca yang di-nisbah-kan kepada seorang lakilaki, dan untuk pembaca perempuan lazim disebut dengan qariah. Kaitannya dengan penyampaian syarh al-Quran, qari atau qariah ini adalah orang yang bertugas membacakan ayat suci al-Quran yang dijadikan landasan oleh pensyarah dalam menyampaikan syarh al-Quran. Qari atau qariah dalam syarh al-Quran, harus melantunkan ayat suci al-Quran secara mujawwad (menggunakan naghamat tilawah) sekurangkurangnya tiga lagu ${ }^{16}$ yang disesuaikan dengan isi kandungan dari ayat-ayat tersebut.

Qari atau qariah merupakan unsur kedua, bukan berarti tidak memiliki peranan penting dalam penyampaian syarh alQuran. Qari atau qariah dalam syarh alQuran, ketika melantunkan ayat suci alQuran, tidak membaca mushaf al-Quran, tetapi ayat-ayat tersebut harus dihafalkan dan lazimnya dilantunkan sambil berdiri, sama seperti pensyarah dan saritilawah.

3. Saritilawah

Saritilawah adalah unsur yang bertugas menyampaikan terjemahan ayat suci alQuran yang telah dibacakan oleh qari atau qariah ke dalam bahasa Indonesia yang baik dan benar. Gaya penerjemahan saritilawah dalam syarh al-Quran adalah model terjemahan dengan rujukan terjemahan H.B. Yasin ${ }^{17}$, bukan terjemahan biasa seperti terjemahan oleh Kementrian Agama yang ada pada al-Quran terjemahan bahasa Indonesia pada umumnya.

Penerjemahan yang disampaikan oleh saritilawah tidak bebas begitu saja, melainkan ada kaidah-kaidah tertentu dan harus merujuk pada substansi ayat yang Ibid., h.7 sesungguhnya. Sehingga terjemahan ayat suci al-Quran tersebut tidak menyimpang maknanya, tetapi sebaliknya akan sangat indah untuk disimak dan lebih mudah untuk dipahami. Penyampaian terjemahan ayat suci al-Quran dalam syarh al-Quran, harus mengombinasikan antara bahasa lisan dengan bahasa gerak.

Berdasarkan penjelasan di atas, maka pensyarah sebagai unsur utama dalam penyampaian syarh al-Quran, dituntut untuk memenuhi berbagai kriteria dan syarat. Menguasai beberapa disiplin ilmu, kekuatan hafalan, kepribadian yang baik, keterampilan berbicara, serta kemapuan menyusun diksi yang menarik. Dengan demikian, untuk menjadi seorang pensyarah, butuh persiapan yang matang. Terlebih lagi pensyarah setara dengan seorang muballigh. Hal-hal yang harus dikuasai oleh seorang pensyarah, antara lain:

1. Menguasai dan mendalami al-Quran dan hadis sebagai materi pokok syarh al-Quran.

2. Mengetahui dan memahami ilmu tablig atau retorika agar mempermudah dalam menyampaikan syarh al-Quran.

3. Memiliki kepribadian yang baik dan pandai mengatur penampilan (good looking).

4. Menguasai keterampilan-keterampilan sebagai berikut: ${ }^{18}$

a. Ilmu tafsir

b. Ilmu hadis

c. Qaul al-Hakim

d. Bahasa Arab (Kaidah-kaidah lughawiyyah)

e. Ushul fiqh

f. Syi'ir atau peribahasa

g. Kemampuan membuat dan menghafal konsep dengan cepat

h. Rajin mengakses berita aktual dan faktual

18 Tata Sukayat, Kapita Selekta Syarhil Quran, (Bandung: CMM UIN SGD, 2001), h. ix 
i. Memahami banyak ungkapan tokoh

j. Menguasai banyak buku referensi

Begitu juga dengan seorang pembaca ayat al-Quran, yakni qari atau qariah dalam syarh al-Quran yang tentunya berbeda dengan qari atau qariah yang pada umumnya melantunkan al-Quran dengan maqamat yang berurutan. Qari atau qariah dalam syarh al-Quran dituntut untuk bisa tilawah sambil berdiri dan menyesuaikan lagu dengan kandungan ayat. Oleh karena itu, qari atau qariah dalam syarh alQuran dituntut untuk: ${ }^{19}$

1. Memiliki kemampuan membaca, memahami, dan menulis ayat-ayat al-Quran.

2. Memahami dan menguasai ilmu tajwid, ilmu qira'at, makharijul hurf, shifatul huruf, dan lainnya.

3. Menguasai naghamat dan maqamat (seni baca al-Quran dan tangga lagu tilawah alQuran).

4. Memiliki kemampuan mengelola napas untuk membaca al-Quran sambil berdiri.

5. Memiliki kemampuan menghafal ayat-ayat al-Quran.

Adapun seorang saritilawah dalam syarh al-Quran harus mengikuti kaidah yang berbeda dengan saritilawah biasa. Model penerjemahan yang disampaikan dalam bentuk deklamasi puisi. Oleh karena itu, keterampilan yang harus dikuasai oleh saritilawah adalah: ${ }^{20}$

1. Memiliki talenta vokal yang bagus.

2. Mampu menghayati isi dan kandungan ayat.

3. Memiliki kemampuan untuk mengekspresikan isi dan kandungan al-Quran dalam bahasa lisan dan gerak secara komunikatif.

4. Menguasai teknik khitabah atau retorika.

5. Mampu menerjemahkan ayat al-Quran secara akurat.

Amirullah Syarbini, Training...op.cit., h. 9

20 Amirullah Syarbini, Bunga Rampai Syarhil Quran,(Banten: Mumtaz Press, 2007), h.3

\section{Strategi Pembinaan Dakwah Syarh al-Quran di Padepokan Syarhil Quran Lampung}

Syarh al-Quran dengan kegiatan dakwah tidak bisa dipisahkan. Syarh al-Quran merupakan salah satu bentuk tablig yang merupakan bagian dari dakwah bi al-lisan. Jadi dengan kata lain, apabila kita melakukan tablig syarh alQuran, berarti telah disampaikan dakwah bi al-lisan. Keunggulan dakwah syarh al-Quran karena komposisi pelaku syarh al-Quran lebih dari satu unsur, yaitu pensyarah, saritilawah, dan qori/qoriah. Dengan harmonisasi tiga unsur tersebut, akan melahirkan sajian yang menyenangkan untuk dinikmati namun tetap padat berisi. Ini adalah sebuah strategi yang ditempuh untuk menyampaikan isi dan kandungan al-Quran yang dalam pandangan masyarakat umum terkesan berat dan membosankan.

Melalui strategi pembinaan yang tepat, strategi pemasaran yang mantap, serta peningkatan kualitas syarh al-Quran yang disesuaikan dengan kebutuhan zaman, syarh al-Quran dapat memiliki peranan penting dalam ekspansi dakwah Islamiyah. Dengan dakwah syarh alQuran tersebut, artinya Islam telah memiliki model dakwah yang unik dan cukup efisien memenuhi unsur edukasi, estetika, dan kehandalan public speaking yang memiliki tempat kekaguman tinggi di masyarakat Indonesia bahkan dunia. Oleh karena itu, dalam usaha meneruskan jejak langkah dakwah Rasul, Syarh al-Quran mencoba menyajikan sebuah dakwah bi al-lisan yang spesial. Menggali pesan-pesan al-Quran lebih dalam, dikaitkan dengan hadis dan sumber ilmu lainnya, disajikan dengan elok dan harmoni oleh ketiga unsur penyampaiannya.

Dalam mewujudkan itu semua, ternyata di Provinsi Lampung terdapat Padepokan Syarhil Quran Lampung yang secara intensif membina dan mencetak kader-kader pendakwah syarh 
al-Quran. Selama ini kader pendakwah syarh al-Quran muncul hanya bagi mereka yang memiliki bakat dan kesempatan saja. Karena selama ini kader pendakwah syarh al-Quran hanya dibina di sekolah-sekolah atau pesantrenpesantren yang notabene lembaga-lembaga pendidikan tersebut tidak fokus dalam peminatan pengembangan seni Islami.

Padepokan Syarhil Quran Lampung yang berada di wilayah Kota Bandar Lampung, menjadi pusat kegiatan kaderisasi pendakwah syarh al-Quran di Indonesia. Inilah rumah sekaligus lembaga pendidikan nonformal yang bisa menghasilkan bibit-bibit unggul apabila dioptimalkan dengan baik. Ide tentang pendirian Padepokan Syarhil Quran Lampung berawal dari keinginan Pembina utama, yaitu Ahmad Rajafi bersama Ahmad Sahida al-Hadi untuk mengubah imej syarh al-Quran yang yang tadinya dimarjinalkan menjadi sebuah sajian yang berkelas dan eksklusif. Karena selama ini syarh al-Quran masih kalah peminatan dan perhatiannya dibandingkan tilawah al-Quran dan hifzh al-Quran. Akhirnya pada tahun 2006, Ahmad Rajafi beserta Ahmad Sahida al-Hadi membuka training syarh al Quran. Awal mula berjalan, beliau mendatangi sekolah-sekolah, diniyah-diniyah, serta pesantren-pesantren untuk mensosialisasikan dan mentraining murid-murid dan santri-santri di tempat tersebut mengenai kecakapan bersyarh alQuran.

Padepokan ini membina kader secara optimal sehingga imej dakwah syarh al-Quran kini telah berubah. Dakwah syarh al-Quran tidak hanya sekadar mata lomba yang dilakukan oleh anak-anak setingkat SMA, melainkan menjadi sebuah metode dakwah baru yang responsif di masyarakat. Acara-acara kedinasan, undangan pernikahan kini seringkali mengun- dang kader-kader syarh al-Quran untuk menyampaikan isi dakwahannya.

Adapun dalam menjalankan kegiatan pembinaan dakwah syarhil Quran tersebut di tubuh Padepokan Syarhil Quran Lampung, strategi yang dilakukan adalah: ${ }^{21}$

1. Pembinaan Penguasaan Naskah Syarh alQuran

Dalam pembinaan penguasaan naskah syarahan al-Quran, pola yang diterapkan adalah:

a. Pada pertemuan perdana, setiap anggota baru diberikan sebuah teks syarh al-Quran. Kemudian dalam waktu satu pekan, mereka diharuskan dapat menyetorkan hafalan mereka minimal dua halaman serta dapat memahami maksud dari teks syarh al-Quran tersebut.

b. Pada pertemuan berikutnya, dijelaskan apa dan bagaimana maksud sesungguhnya dari teks syarh al-Quran yang ia sedang pelajari. Diajarkan bagaimana cara menghayatinya, dan kemudian diberitahukan tekanan-tekanan penting dalam naskah tersebut.

c. Selanjutnya mereka (anggota baru) diharuskan untuk menyelesaikan hafalan teks perdana tersebut dan diwajibkan untuk menyetorkan hafalan teks secara utuh dalam waktu tiga pekan.

d. Pada pekan ke empat, barulah perangkat elektronik ataupun gadget seperti recorder, handphone, dan mp4 diperkenankan untuk digunakan merekam suara para anggota baru. Kemudian diperdengarkan kembali kepada anggota baru, agar mereka dapat menilai penyampaian mereka sendiri, sudah baik ataukah belum baik dari segi 
intonasi, artikulasi, dan lainnya. Dengan demikian, setiap anggota baru diharuskan untuk dapat menilai diri sendiri sebelum menilai orang lain.

e. Setelah itu, setiap bulannya anggota mendapatkan sebuah contoh rekaman suara pembina atau para mentor untuk didengarkan kapan pun agar mereka terbiasa dengan penyampaian yang benar.

f. Pada pekan ke enam, para anggota baru atau peserta binaan harus sudah dapat menyampaikan teks syarh-an sesuai dengan apa yang telah diarahkan dalam rekaman yang telah diterima oleh masing-masing peserta.

g. Bagi mereka yang telah mampu menyampaikan teks syarh-an dengan vokal yang baik, maka akan dilanjutkan ke pelatihan hafalan berikut dengan gestur dan mimik yang tepat.

h. Pada akhir pekan ke delapan, dilakukan evaluasi keseluruhan dengan masingmasing mentor. Kemudian ditampilkan di hadapan Pembina agar mendapat arahan yang lebih baik dan sesuai dengan kaidah penyampaian syarh alQuran.

\section{Pembinaan Mental}

Sudah menjadi rahasia umum, tampil di depan banyak orang membutuhkan kesiapan fisik, kecerdasan dan mental. Banyak orang yang gugup dan gemetar untuk berbicara di depan audiens yang banyak. Bahkan, banyak para pemimpin negara yang sengaja meminta jasa penasihat komunikasi untuk melatih gaya berpidato mereka di depan masyarakatnya.

Pembinaan yang cepat dan tepat untuk menghadapi hal tersebut ialah dengan melawan arus rasa takut sesuai dengan ketakutan masing-masing individu. Adapun pembinaan mental yang dilakukan oleh padepokan adalah dengan langsung turun ke area keramaian seperti Lapangan Enggal, PKOR Way Halim, Bundaran Tugu Adipura Bandar Lampung, area pasar, dan tempattempat lain di mana orang-orang banyak berkumpul, terutama di hari Minggu. Kemudian membiasakan untuk tampil satu grup dalam acara majelis taklim, dan pengajian.

Pembinaan mental ini menjadi prioritas kedua setelah menghafal, karena penampilan syarh al-Quran sangat berbeda dengan yang lain. Selain karena penampilan yang harus disajikan sejara berdiri tanpa mimbar, syarh al-Quran juga sangat menguras tenaga. Dengan pelatihan mental yang kuat, otak kanan dan kiri akan bekerja secara sinergi. Pikiran, ucapan, dan gestur akan selaras dalam penyampaiannya. Ada empat tahap pembinaan mental di Padepokan Syarhil Quran Lampung:

a. Pembinaan mental tahap satu

Latihan awal ini dilakukan dengan cara menyampaikan secara bersama-sama naskah yang sudah dihafal dengan suara yang lantang. Di sini akan terhilat kekuatan hafalan dan kekuatan konsentrasi peserta binaan syarh al-Quran. Latihan seperti ini harus terus dilakukan berulang-ulang hingga semua peserta binaan memiliki konsentrasi yang kuat terhadap hafalannya.

b. Pembinaan mental tahap dua Latihan mental tahap kedua ialah dengan berlatih langsung di tengah keramaian. Latihan bisa dilakukan di seputar arena olah raga, jalan raya, pasar, dan sebagainya. Fungsi utama pembinaan tahap dua ini ialah 
memantapkan mental dan konsentrasi yang telah dilatih sebelumnya jika pada tahap satu masih bersama para peserta binaan yang lain, tahap kedua ini peserta harus siap menerima reaksi dari masyarakat yang ada di arena berlatih. Mulai dari reaksi melihat dengan aneh, sampai dengan terangterangan mengejek "gila".

c. Pembinaan mental tahap tiga

Pembinaan tahap ketiga ialah dengan mengelompokkan peserta binaan menjadi satu grup syarhil yang utuh. Peserta-peserta binaan yang sudah digabungkan dalam sebuah grup, akan berlatih secara bersama-sama sebagai sebuah kesatuan tim agar timbul rasa kebersamaan dan ikatan sehingga akan menghasilkan sebuah harmoni syarh al-Quran. Dengan membangun hubungan yang baik, mereka akan saling koreksi, belajar mandiri, dan saling memberi nasihat yang membangun.

d. Pembinaan mental tahap empat Latihan mental tahap terakhir ialah dengan menampilkan mereka ke majelis-majelis taklim, pengajian para pejabat, acara pernikahan, muhadharah pondok-pondok pesantren, dan syukuran. Kegiatan-kegiatan lapangan yang terus digalakkan akan menambah gairah dan semangat untuk terus menampilkan yang terbaik dalam penyampaian syarh al-Quran. Mereka akan terus dan terus belajar untuk meningkatkan kualitas diri.

3. Pelatihan Vokal dan Performa

Bicara masalah vokal berarti berbicara tentang penciptaan intonasi dan artikulasi yang terhadap segala yang terucap dari lisan setiap individu. Banyak sekali terjadi berbagai ungkapan yang terlontar dengan nada dan dialek daerah masing-masing. Untuk itu, merupakan kewajiban untuk berusaha yang keras dari setiap peserta binaan agar mampu merubah kebiasaan dialek kedaerahan dengan latihan vokal.

BAG. 1 MARI “A”, “"', "U”, “ “"”, “O”

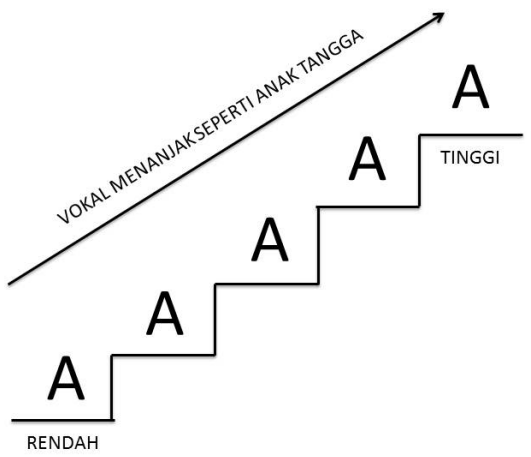

Pada bagian pertama, setiap individu harus mendapatkan suara vokal yang terendah hingga tertinggi dengan model seperti anak tangga. Setiap individu harus merasakan betul di mana letak suara vokal terendah mereka, suara sedang hingga paling tinggi. Untuk itu, konsentrasi menjadi modal utama dalam latihan. Hal ini menjadi penting karena sering kali didapatkan di dalam penampilan syarhil Quran, para peserta hanya mengandalkan suara yang keras agar terdengar tegas padahal sangat terlihat monoton.

Pada bagian yang kedua, setiap individu akan belajar tentang bagaimana menciptakan nada, intonasi yang dirasa pas dan cocok dengan model suaranya. Nada tidak perlu tinggi atau keras, akan tetapi irama yang pas dengan isi teks adalah keutamaan, karena isi sebuah teks merangkum berbagai suasana, seperti sedih, marah, tegas, mengajak, dan lain sebagainya. Jika setiap individu mampu menguasai latihan vokal yang kedua ini, maka dampak langsungnya 
adalah terbawanya para audience dengan suasana yang diungkapkan oleh peserta, baik dari seorang pensyarah ataupun penterjemah.

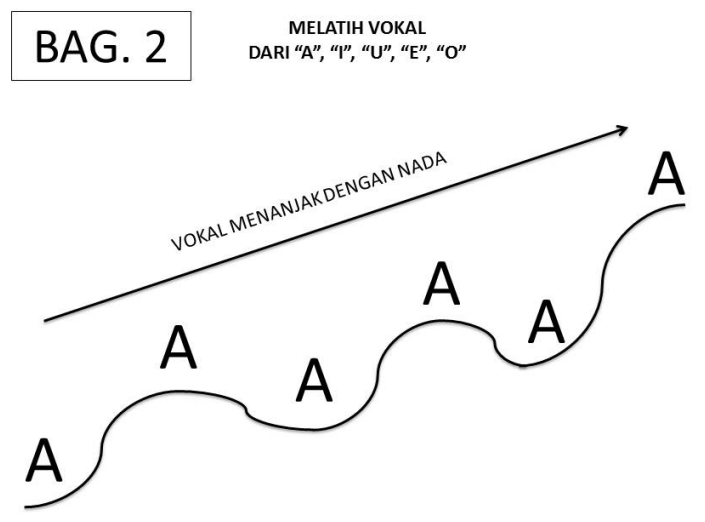

Latihan vokal bagian yang ketiga dimaksudkan untuk menstabilkan suara vokal yang telah dilatih pada bagian pertama dan kedua. Sifatnya adalah untuk kembali merasakan hasil dari latihan sebelumnya. Untuk itu, pada bagian ini, dibutuhkan kerja sama dari peserta lainnya untuk saling mendengarkan dan mengoreksi apakah sudah cukup tepat atau butuh latihan lagi pada bagian sebelumnya. Kerja keras harus ditunjukkan bagi mereka yang masih sangat kental dengan nada kedaerahannya, seperti model Jawa, Sunda, Padang, Lampung, dan sebagainya.

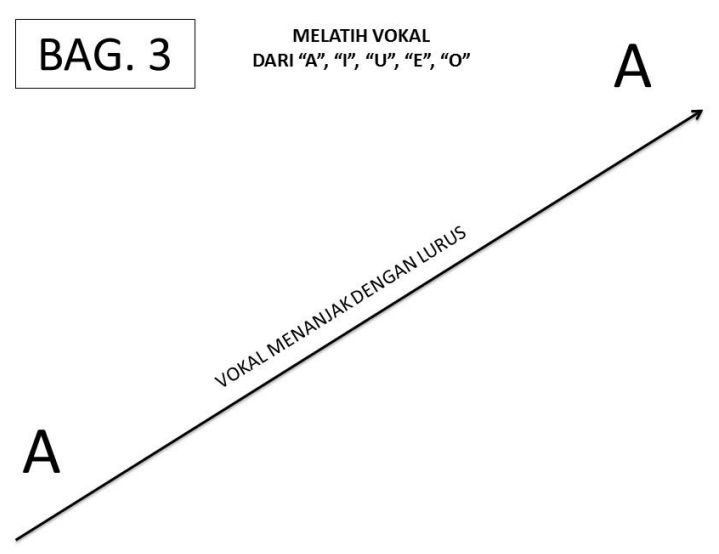

Selanjutnya setelah usai melatih vokal, para peserta binaan mulai memasuki ranah latihan fisik berupa performa penampilan di atas podium. Dalam hal ini, materi awal menjelaskan tentang bagaimana sudut atau arah pandangan yang tepat ketika tampil di hadapan penonton. Sebagai petunjuk awal, para peserta binaan hanya diarahkan kepada tiga sudut pandang dan tidak berubah, akan tetapi ketika setelah ia menikmati maka ia akan dapat menguasai dengan mudah arenanya.

Dalam hal ini, setiap peserta memiliki kebebasan dalam berekspresi, baik mimik ataupun gaya/gerak ketika waktu yang betul-betul milikinya. Artinya, ketika bukan waktunya maka setiap person hanya boleh diam dan tidak boleh melakukan aktivitas apapun yang dapat menggangu dan merusak penampilan. Untuk itu, dalam latihan setiap peserta ditanamkan penekanan, bahwa ketika bukan gilirannya untuk menampilkan penampilannya maka pandangannya hanya tertuju ke bawah searah dengan tinggi badan. Maksudnya adalah, wajah dan tubuh tetap tegak dan membusung ke depan, hanya pandangan mata saja yang tertuju ke bawah. Hal ini dilakukan agar mereka dapat lebih mudah untuk mereview hafalannya.

Adapun tentang performa tampil para anggota grup, disesuaikan atas dasar kesepahaman atau diskusi antaranggota grup, intinya hanyalah kesopanan dan keserasian semata yang dibangun oleh masing-masing grup. Jangan sampai karena tidak ada keserasian antar masing-masing anggota lalu nilai kesopanan dan keserasian menjadi berkurang.

4. Pembinaan Spritual 
Pembinaan spritual juga sangat ditekankan di dalam pelatihan dakwah syarh al-Quran. Biasanya para kader yang dilatih dan kemudian merasa dirinya mampu dan bagus, akan muncul kesombongan dan dapat merusak performa tampilan grup. Tidak sedikit grup-grup yang dianggap terbaik berbalik terpuruk karena kesombongan, bahkan sampai ada yang tidak jadi tampil karena accident di dalam grupnya. Pembinaan spritual yang paling utama adalah dengan membiasakan para peserta binaan untuk berzikir dengan amalan-amalan yang telah diajarkan di dalam padepokan.

Selain itu, diadakan pula khataman alQuran di setiap bulannya. Fungsi utamanya adalah, agar mereka betul-betul dapat menjadi ahl al-Quran (keluarga al-Quran) sehingga ketika mereka akan mensyarah isi kandungan al-Quran maka dengan sendirinyaal-Quran tersebutakan membimbingnya. Hal ini sejalan dengan hadis Rasulullah Muhammad saw.:

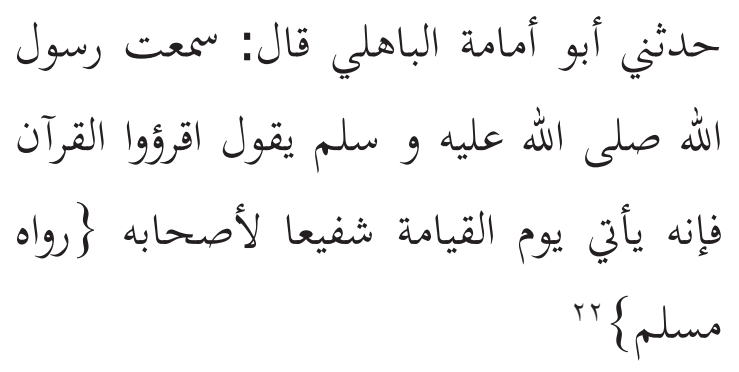

Artinya: "Disampaikan kepadaku oleh Abu Umamah al-Bahili berkata; aku mendengar Rasulullah saw. bersabda; bacalah al-Quran, karena sesungguhnya ia akan datang pada hari kiamat untuk memberikan syafa'at bagi yang membacanya." (HR. Muslim)

Setelah membiasakan mereka untuk berzikir dengan ayat-ayat Allah, maka

22 Muslim bin al-Hajjaj Abu al-Husein al-Qusyairi an-Nisaburi, Shahih Muslim, (Beirut: Dar Ihya' at-Turats al-Arabi, t.th), Juz. 1, h. 553 pembinaan selanjutnya adalah dengan membiasakan mereka untuk men-dawamkan shalat sunnah dhuha' dan tahajud. Di sinilah ikatan spiritual akan tersambung dengan kuat antara anggota grupnya, caranya adalah dengan selalu saling mengingatkan setiap waktu-waktu ibadah tersebut telah masuk. Dan dikala mereka sedang tidak berada di satu tempat, maka hand phone menjadi sangat berfungsi efektif untuk saling membangunkan.

Pembinaan spiritual yang terakhir adalah dengan membiasakan mereka untuk berpuasa sunnah, baik puasa sunnah SeninKamis ataupun puasa sunnah Nabi Daud. Di sinilah mental dan spritual akan menyatu secara sempurna. Mereka tidak akan lagi takut kalah bahkan terobsesi untuk menjadi juara. Bagi mereka, dengan menampilkan penampilannya secara maksimal, meskipun yang menjadi juara adalah teman-teman mereka, maka rasa ikhlaslah yang hadir, dan bukan menjadi saling iri bahkan membenci.

5. Pembinaan Kekeluargaan

Penampilan dakwah syarh al-Quran adalah penampilan grup dan bukan perseorangan, artinya dibutuhkan kekompokkan dan rasa kebersamaan dalam penampilan dakwah tersebut. Untuk itu, menjadi sangat urgen ikatan kekeluargaan di dalam padepokan, meskipun pada awalnya mereka berkumpul dari daerah yang berbeda-beda dan tentunya belum pernah saling kenal-mengenal.

Namun demikian, di dalam padepokan ada satu buah kebiasaan, yakni susah bersama-sama dan senang bersama-sama. Untuk itu di padepokan diajarkan tentang pentingnya berbagi, jika satu grup mendapatkan rezeki kejuaraan, maka mereka akan memberikan satu dari tiga hadiah yang ada ke pengurus agar dapat dibagi- 
bagi untuk semua, seperti para pelatih, uang kas dan bahkan termasuk untuk teman-teman yang belum merasakan juara, namun juga mendapatkan kebahagiaan bersama dengan para juara.

Sistem seperti ini diterapkan di dalam padepokan untuk menghindari penyelewengan hak dan kewajiban di lapangan yang kemudian dapat menimbulkan fitnah dan dosa. Itupun jika mereka juara dan mendapatkan reward dari kejuaraannya, adapun jika tidak juara dan tidak ada reward maka tidak ada pembagian apapun. Oleh karena itu, prinsip dasar dalam pembinaan kekeluargaan tersebut adalah jujur dan ikhlas.

Metode simpelnya adalah dengan membiasakan anak-anak untuk saling merasakan suka dan duka dalam keluarga, di dalam padepokan apa yang guru makan maka itu pula yang dimakan oleh mereka, bahkan antara guru dan para peserta binaan dibiasakan untuk makan bersama-sama dalam satu wadah, dan jika ada salah satu anggota yang sakit, maka sesama anggota padepokan akan saling mengurusi dan menjaga. Hal ini sejalan dengan hadis Rasulullah Muhammad saw:

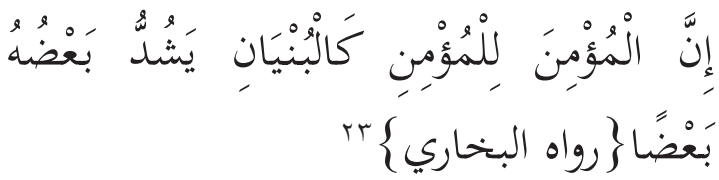

Artinya: "Sesungguhnya seorang mukmin dengan mukmin lainnya seperti satu bangunan, yang saling melengkapi satu sama lainnya." (HR. al-Bukhari)

Berdasarkan strategi yang dibangun oleh Padepokan Syarhil Quran Lampung tersebut

23 Muhammad bin Ismail Abu Abdillah al-Bukhari, al-Jami'ash-Shahih al-Mukhtashar, (Beirut: Dar Ibn Katsir, 1987), Juz. 1, h. 182 maka dapat dipahami bahwa fungsi utama dari hal itu semua adalah:

1. Untuk menyampaikan kebenaran Islam (atTablig wa al-Bayan)

Tugas menyampaikan kebenaran disebut dengan tablig, yang secara harfiah berarti menyampaikan sesuatu kepada pihak lain. Dalam al-Quran, tablig dalam berbagia bentuknya diulang sebanyak 25 kali, yakni dalam bentuk ballagha tujuh kali, ablagha empat kali, dan balagh sebanyak 14 kali. $^{24}$ Namun, dakwah tidak cukup hanya mengajak melalui lisan, tapi juga harus melalui keteladanan. Menyampaikan kebaikan tidak hanya melalui pidato tapi juga dengan mencontohkannya kepada anak-anak, sahabat, dan orang-orang di manapun kita berada. Untuk itulah syarhil Quran dihadapkan kepada masyarakat untuk menunjukkan keteladan melalui seni.

2. Amar Makruf Nahi Mungkar

Amar makruf nahi mungkar diambil dari rangkaian ayat di dalam al-Quran yakni al'amru bi al-ma'ruf wa an-nahyu 'an almunkar. Yakni sebuah frasa dalam bahasa Arab yang maksudnya sebuah perintah untuk mengajak atau menganjurkan hal-hal yang baik dan mencegah hal-hal yang buruk bagi masyarakat. Frasa ini dalam syariat Islam hukumnya adalah wajib. Berarti wajib hukumnya menyampaikan kebaikan dan melarang pada keburukan, termasuk melalui dakwah syarh al-Quran yang ditampilkan dengan performa seni di hadapan masyarakat.

Oleh karena fungsi yang begitu besar dibebankan dalam dakwah syarh al-Quran tersebut, maka isi dari sebuah naskah syarh al-Quran harus memiliki bobot keilmuan yang tinggi, namun tetap dengan penyampaian yang

24 Muhammad Fuad abd al-Baqi, al-Mu'jam al Mufahros lil Fadzhil Quran, (Beirut: Daarul fikr, 1987), h.125 
memikat umat. Seperti mengenai ayat yang dipilih dalam syarahan al-Quran, di mana ayat yang telah dipilih sebagai kajian utama, wajib dipaparkan tafsirannya. Kitab tafsir tentu bermacam macam, mulai dari penulisan ulang kitab tafsir klasik, hingga munculnya kitab tafsir modern dan kitab tafsir tematik. Maka sumber-sumber tersebut dapat dicantumkan dalam naskah syarahan al-Quran. Dan dalam syarh al-Quran, tafsir sedapat mungkin diolah redaksinya agar mudah untuk disampaikan dan dipahami oleh audiens, namun tidak mengubah substansi dari ayat.

Tafsir ayat ditekankan pada pesan penting dari ayat tersebut dengan dikontekstualisasikan pada era kekinian, seperti berupa beberapa ulasan kata penting oleh mufassir. Setelah maksud ayat diuraikan, kemudian diuraikan sesuai konteks kekinian bahkan ke-Indonesiaan dan didukung oleh data yang diakses dari lembaga yang dapat dipertanggungjawabkan seperti Badan Pusat Statistik (BPS) sebagai refleksi.

Selain tafsir ayat al-Quran, dibutuhkan pula dalil-dalil pendukung seperti asbab nuzul (sebab turun ayat), hadis, sya'ir, atau kata-kata mutiara sebagai bahan tambahan untuk syarahan ayat al-Quran. Harus berhati-hati dalam pemilihan bahan tambahan ini karena banyak sumber yang tidak valid. Ada ayat yang memiliki banyak versi asbab nuzul, apalagi hadis. Oleh karena itu, kemampuan ulum al-hadis diperlukan untuk dapat mengidentifikasi validitas dari sebuah hadis.

Adapun penggunaan dalil dapat diklasifikasikan dalam dua bagian, yaitu dalil naqli dan dalil 'aqli. Dalil naqli dapat berupa penyebutan ayat al-Quran, hadis, maupun ungkapan ulama. Sedangkan dalil 'aqli dapat berupa pendekatan filosofis, historis, maupun antropologis. Menjadi sebuah catatan penting, bahwa kalimat yang digunakan dalam berdalil adalah dengan tidak terlampau jauh dari maksud syarh-an, tidak fokus sehingga mengaburkan maksud awal pensyarh-an. Untuk itu, ditekankan tentang pentingnya menghindari penyampaian yang tidak langsung pada maksud dan tujuan.

Selain daripada itu, hendaknya pula kalimat-kalimat yang digunakan dalam mengungkapkan dalil dapat membuat kesan yang mengena di hati para pendengar dakwah syarh alQuran. Kalimat tersebut harus diolah sehingga masalah yang dipaparkan dalam syarahan penting untuk diperhatikan, dijadikan bahan kajian, dan segera diambil tindakan sebagai solusi.

\section{Kesimpulan}

Dakwah melalui syarh al-Quran merupakan jalan yang cukup efektif untuk mendakwahkan isi dan kandungan al-Quran kepada masyarakat. Penampilannya yang menarik dan komunikatif, menggabungkan tiga unsur yang berbeda namun begitu harmoni, membuat penjelasan isi dan kandungan al-Quran tidak menyeramkan tetapi lebih ringan dan mudah dipahami. Hal ini sudah berhasil dilakukan oleh pembina Padepokan Syarhil Quran Lampung di Provinsi Lampung, dengan strategi utama:

1. Mengenal khalayak, dilakukan dengan berlatih di tempat umum dan mengidentifikasi kebutuhan masyarakat akan informasi mengenai nilai-nilai keislaman dalam alQuran.

2. Menyusun isi pesan, dengan pelatihan hafalan teks dan latihan pembuatan naskah. Bagaimana format syarh al-Quran disusun.

3. Memilih metode, metode yang dipilih ialah persuasif dan informatif. Metode ini terus dilatih dngan pembelajaran-pembelajaran khusus dan bertahap. Membangun pondasi yang kuat dalam pemahaman syarh al- 
Quran bagi setiap peserta binaan padepokan melalui berbagai pembinaan, mulai dari semua pembinaan yang berkenaan dengan penguasaan konsep dan penyajian syarh al-Quran sampai pembinaan spiritual dan kekeluargaan.

4. Strategi pengenalan syarh al-Quran, dilakukan dengan membangun dan memperluas link untuk berdakwah yang dilakukan oleh pembina dan para peserta. Pembina membangun link melalui silaturahmi dan kapasitasnya sebagai insan akademisi, mubalig, dan dewan hakim Provinsi Lampung untuk membuka jalan agar syarh al-Quran dapat digemakan di seluruh Lampung. Ditambah juga dengan peserta mencetak prestasi sebanyak-banyaknya dan setinggi-tingginya. Dengan prestasi yang tinggi, kepercayaan masyarakat terhadap kapabilitas peserta binaan Padepokan Syarhil Quran Lampung akan melekat pada diri peserta yang berprestasi tersebut. Apabila kepercayaan telah didapatkan, akan semakin memudahkan jalan untuk berdakwah melalui syarh al-Quran.

5. Mengubah citra syarh al-Quran yang tadinya belum populer dan dimarjinalkan, menjadi sebuah sajian yang edukatif, komunikatif, sekaligus elegan. Dengan selalu mengenakan kostum yang rapi dan good looking serta penyampaian yang berwibawa.

\section{DAFTAR PUSTAKA}

Ismail, A. Ilyas. Paradigma Dakwah Sayyid Quthub: Rekonstruksi Pemikiran

Dakwah Harakah, Jakarta: Penamadani, 2008.

Toto Tasmara. Komunikasi Dakwah. Jakarta: Graha Media Pratama, 1997, h. 1
Effendy, Onong Uchjana., Ilmu, Teori, dan Filsafat Komunikasi, Bandung: Citra Aditya Bakti, 2003.

-. Peranan Komunikasi Massa Dalam

Pembangunan, Yogyakarta: Gadjah Mada University, 1987.

Sapuri, Rafy. Psikologi Islam, Jakarta: PT. Raja Grafindo Persada, 2009.

Rajafi, Ahmad. Narasi Syarhil Qur'an: Kompilasi Teks Syarhil Qur'an dan Model Pembinaannya, Bandar Lampung: Aura Publishing, 2013

Arifin, Anwar. Strategi Komunikasi Sebuah Pengantar Ringkas, Bandung: Amrico, 1994.

Sukayat, Tata. Kapita Selekta Syarhil Quran, Bandung: CMM UIN SGD, 2001.

Amirullah, Syarbini. Bunga Rampai Syarhil Quran, Banten: Mumtaz Press, 2007.

Muslim bin al-Hajjaj Abu al-Husein al-Qusyairi an-Nisaburi. Shahih Muslim, Beirut: Dar Ihya' at-Turats al-Arabi, t.th.

Muhammad bin Ismail Abu Abdillah al-Bukhari. Al-Jami' ash-Shahih al-Mukhtashar, Beirut: Dar Ibn Katsir, 1987.

Muhammad Fuad abd al-Baqi. al-Mu'jam alMufahras li Alfazh al-Quran, Beirut: Dar al-Fikr, 1987. 